\title{
Evaluation of the mangrove system in the estero "Arroyo los Coamiles" (Punta de Mita, Nayarit, Mexico)
}

\section{Evaluación del sistema de manglar en el estero "Arroyo los Coamiles"(Punta de Mita, Nayarit, México)}

PÉREZ-PEÑA, Martín†**, \& ROBLES-JARERO, Elva Guadalupe

Universidad de Guadalajara-Laboratorio de Ecosistemas Marinos y Acuicultura, Depto. de Ecología. Centro Universitario de Ciencias Biológicas y Agropecuaria, Ramón Padilla Sánchez 2100, Nextipac, 44600, Zapopan, Jal, México.

ID $1^{\text {st }}$ Author: Martín, Pérez-Peña / ORC ID: 0000-0002-9479-0722, CVU CONACYT ID: 1012062

ID $1^{\text {st }}$ Coauthor: Elva Guadalupe, Robles-Jarero / ORC ID: 000-0003-2537-671X, CVU CONACYT ID: 59946

DOI: $10.35429 / J E S N .2020 .17 .6 .10 .16$

Received April 26, 2020; Accepted June 30, 2020

\begin{abstract}
In March 2019, the current state of the mangrove structure in the Arroyo los Coamiles estuary (Punta Mita Bay, Nayarit) was evaluated. The method of circular plots centered on a point was used (Cottam and Curtis, 1956). The mangrove structure is made up of the species Laguncularia racemosa, Avicennia germinans, Conocarpus erectus and Rhizophora mangle. The greatest forest development is found in the second third of the estuary with a bordercontinental structure. The average height of the mangroves was $6.17 \mathrm{~m}$, (SD $7.35 \mathrm{~m})$, the diameter at breast height was $19.21 \mathrm{~cm}$ and the total basal area was $57.36 \mathrm{~m}^{2}$. The data are associated with young trees in a good state of development and conservation. The $\mathrm{C} / \mathrm{N}$ ratio was determined as an index of the quality of the soil organic substrate, the values ranged between 3.74 and 14.91 and the percentage of organic matter was from 1.45 to 8.04 . The fragility of the soils reinforce the proposal to take care of the natural drainage of the property. Mangroves have been impacted by tourist developments around the world, the environmental and economic benefits that these ecosystems provide are ignored by inhabitants and authorities, which allow their destruction.
\end{abstract}

\begin{abstract}
Resumen
En marzo de 2019, se evaluó el estado actual de la estructura del manglar en el estero Arroyo los Coamiles (Punta Mita, Nayarit). Se utilizó el método de parcelas circulares centradas en un punto (Cottam y Curtis, 1956). La estructura del manglar está conformada por las especies Laguncularia racemosa, Avicennia germinans, Conocarpus erectus $y$ Rhizophora mangle. El mayor desarrollo forestal se encuentra en el segundo tercio del estero con estructura tipo borde-continental. La altura promedio de los manglares fue de $6.17 \mathrm{~m}$, (DE $7.35 \mathrm{~m}$ ), el diámetro a la altura del pecho fue de $19.21 \mathrm{~cm}$ y el área basal total de $57.36 \mathrm{~m}^{2}$. Los datos se asocian a árboles jóvenes en buen estado de desarrollo y conservación. Se determinó la relación $\mathrm{C} / \mathrm{N}$ como índice de la calidad del sustrato orgánico del suelo, los valores oscilaron entre 3.74 y 14.91 y el porcentaje de materia orgánica fue de 1.45 a 8.04. La fragilidad de los suelos, refuerzan la propuesta de cuidar el drenaje natural del predio. Los manglares han sido impactados por desarrollos turísticos en todo el mundo, los beneficios ambientales y económicos que otorgan estos ecosistemas son ignorados por habitantes y autoridades, que permiten su destrucción.
\end{abstract}

Mangrove, Structure, Nayarit

Manglar, Estructura, Nayarit

Citation: PÉREZ-PEÑA, Martín \& ROBLES-JARERO, Elva Guadalupe. Evaluation of the mangrove system in the estero "Arroyo los Coamiles" (Punta de Mita, Nayarit, Mexico). Journal of Environmental Sciences and Natural Resources. 2020, 6-17: 10-16

\footnotetext{
* Correspondence to Author (email: martin.perez@academicos.udg.mx)

$\uparrow$ Researcher contributing first author.
} 


\section{Introduction}

Mangroves develop in the coastal plains of the humid tropics, around estuaries and coastal lagoons, near the mouths of rivers and streams. They cover less than $0.1 \%$ of the continents, yet contribute more than $10 \%$ of the organic carbon entering the ocean from the continents (Dittmar and Lara, 2001; Dittmar et al., 2001). In our country, four species of mangroves predominate: the red mangrove (Rhizophora mangle), the white mangrove (Laguncularia racemosa), the black mangrove (Avicennia germinans) and the buttonwood mangrove (Conocarpus erectus), which are subject to Special Protection according to NOM 059 SEMARNAT-2001, due to factors that negatively affect their viability, which would determine the need to promote their recovery and conservation (DOF, 2002). The strongly limiting factor of salinity originates a great variability in the composition, structure and function of this ecosystem. At the local level, the characteristics of mangroves are modified according to the relief, the type of substrate, the degree of flooding, environmental gradients and natural and human disturbances.

The high primary productivity of mangroves is widely known, through which they export large amounts of energy, in the form of organic matter (OM) to the adjacent coastal zone. It is estimated that about $250 \mathrm{x}$ 106 tons of dissolved organic carbon enter the world ocean per year (Cauwet, 2002), representing approximately $600 \times 10^{6}$ tons of MO. Mangroves participate as climate moderators by providing humidity through rainfall, are a direct source of natural resources, support important riverine fisheries and provide refuge for endangered wildlife such as birds, reptiles, amphibians and mammals.

Despite the importance of mangroves, their global extent has been considerably reduced (FAO, 2007a). In our country they have been affected by the direct and indirect impact of agricultural, livestock, aquaculture and tourism activities mainly.

Mexico's mangroves on both coasts have been studied by numerous authors (FloresVerdugo et al., 1992; Tovilla, 1994; Portillo and Ezcurra, 2002; Basáñez et al., 2008). However, in the Mexican Central Pacific, studies have been very superficial and focused mainly on species listing and density.
This work was part of a diagnostic study to determine the current status of the mangrove system in the Arroyo los Coamiles estuary, located in a region that has been a pole of urban and tourist development since 1970.

\section{Methodology}

\section{Study área}

Punta de Mita, It has an area of $6.1 \mathrm{~km} 2$, is located in the southwestern part of the state of Nayarit, between the parallels 20-44' and 20-51' latitude $\mathrm{N}$ and the meridians 105-34' and 10524 ' of Longitude W. Have a border to the north with the Pacific Ocean, to the east with Valley of Flags, both belonging to the state of Nayarit, to the west and south with the Pacific Ocean (Figure 1). The estuary Arroyo los Coamiles is located northeast of Corral de Riscos between coordinates 20.7822 or 20 o $46^{\prime} 55.8^{\prime \prime}$ north latitude and $105,5077 \mathrm{o}$ or $105 \mathrm{o} 30^{\prime} 27.7^{\prime \prime}$ of West Longitude, with an altitude of 16 meters (52 feet).

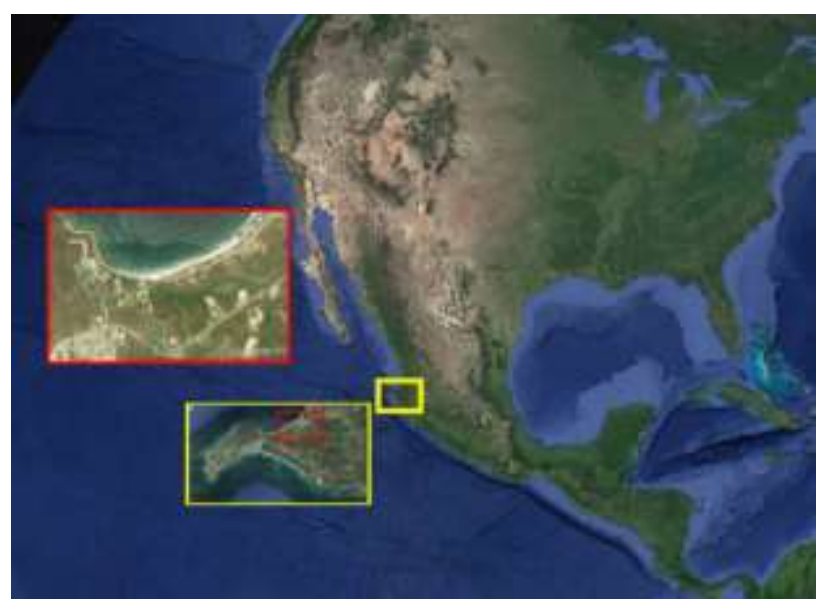

Figure 1 Location of the estuary Arroyo los Coamiles, Punta de Mita, Nayarit, Mexico

The region presents a warm sub-humid climate according to Köppen's classification, modified by Garcia (CONABIO, 2004), with rains in summer and drought in winter. The average annual relative humidity is $80 \%$, being among the highest in the Mexican Pacific. The low season is from November to May, while the rainy season covers the period from June to October, with peaks in August that exceed 320 $\mathrm{mm}$. The average annual precipitation reported is $1200 \mathrm{~mm}$. The highest temperatures occur from May to October and the lowest in the months of December and January. The average annual temperature is $27.1^{\circ} \mathrm{C}$, (CONAGUA, 2015).

PÉREZ-PEÑA, Martín \& ROBLES-JARERO, Elva Guadalupe Evaluation of the mangrove system in the estero "Arroyo los Coamiles" (Punta de Mita, Nayarit, Mexico). Journal of Environmental Sciences and Natural Resources. 2020 


\section{Materials and methods}

The method of circular plots centered on a point modified by Cottam and Curtis, (1956) was used to determine the structure of the mangrove. A central point was placed in each of the five $10 \mathrm{~m}$ diameter plots. The distance from the center point to the nearest tree in each plot was measured and then to 4 more trees. Each tree species whose diameter at breast height $(\mathrm{DBH})$ was greater than $2.5 \mathrm{~cm}$ was identified. The plots were established perpendicular to the water channel through the mangrove in each of the identified types. This method provides a quantitative description of the species composition, community structure and plant biomass, as well as a framework for relating changes in forest structure and growth to hydrological and soil factors.

For this method, measurements are taken in the field from which the frequency of cover, base area, is calculated. Two handheld compasses were used to establish the orientation of the plots (from the coast to the interior of the forest), $60 \mathrm{~m}$ tape measures to establish the central points, two $2 \mathrm{~m}$ tape measures to measure the diameter at breast height (DAP).

The basal area $(\mathrm{AB})$ is derived from the natural diameter (ND) estimates, and should be recorded in any of the mangrove structural parameters in temporary or permanent sampling units (UM). It is an important variable for studies of structure, forest harvesting and productivity of the mangrove. The BA expresses the dominance of the different diameters of the species in a community (Equation 1). It is expressed in $\mathrm{m} 2$ by the area of the MU in one hectare (ha) (Muller-Dombois and Ellenberg 1974), calculated with the following equation:

$A B=\frac{4}{\pi}\left(\frac{D N}{100}\right)^{2}$

Where:

$\mathrm{AB}=$ basal area in $\mathrm{m}^{2}$

$\pi=3.1416$

$\mathrm{DN}=$ normal diameter in $\mathrm{cm}$

From the BA it is possible to estimate the absolute dominance of mangrove species with the following equation:
Dominance $=\frac{A B \text { of a species }}{A B \text { of all species }}$

Where:

$\mathrm{AB}=$ basal area

Density is defined as the number of adult trees per unit area and is expressed in terms of individuals per hectare (Equation 3) (Mueller-Dombois and Ellenberg, 1974):

Density $=\frac{\text { Num.of ind.per } s p}{\text { Num.total of ind.of all the } s p}$

The sum of the density of each species will result in the density of adult trees per hectare and is expressed in individuals per hectare. For UM with specific area sizes, it is possible to estimate the frequency from the density of individuals and species. Species frequency is defined as the number of times individuals of a species occur per unit area (Mueller-Dombois and Ellenberg 1974).

The frequency of species is a complementary variable that is derived from the density of individuals (Equation 4). It can be estimated in any of the structural types of mangrove, in temporary and permanent sampling units. In the former, it is recommended that it be estimated at least every five years, considering the change in species frequency (Mueller-Dombois and Ellenberg, 1974).

Frequency $=\frac{\text { Number of times the sp appears in UM }}{\text { Total number of sample units }}$

To know the mineralization rate of organic matter, the relationship between organic carbon and total nitrogen $(\mathrm{C} / \mathrm{N})$ was used (Sources, 1999). Sediment samples were obtained in three transects perpendicular to the right bank of the estuary. Five points were taken in each transect at a distance of $10 \mathrm{~m}$, starting from the shore without reaching the water level. At each point, a sediment core of $15 \mathrm{~cm}$ depth was collected and deposited in a hermetically sealed plastic bag. They were kept protected from light and at a temperature of 180 to $20 \mathrm{oC}$, to be later analyzed at the Environmental and Organic Fertilizer Laboratory of the CUCBA, of the University of Guadalajara (Table 1). 


\begin{tabular}{|l|l|}
\hline \multicolumn{1}{|c|}{ Determinations } & \multicolumn{1}{c|}{ Method used } \\
\hline Organic matter $(\%)$ & Walker and Black \\
\hline Nitrogen $(\%)$ & Kjeldahl \\
\hline Carbon $(\%)$ & Walker and Black \\
\hline Carbon/Nitrogen Ratio & $(\mathrm{C} / \mathrm{N})$ Calculated \\
\hline Chlorides $(\mathrm{mg} / \mathrm{kg})$ & Degree \\
\hline Bicarbonates $(\mathrm{mg} / \mathrm{kg})$ & Degree \\
\hline Sulfates $(\mathrm{mg} / \mathrm{kg})$ & LV spectrum \\
\hline Nitrates & LV spectrum \\
\hline Phosphates & LV spectrum \\
\hline
\end{tabular}

Tabla 1 Determinación de los componentes del suelo y el método de análisis empleado

\section{Results}

The mangrove structure of the estuary "Arroyo los Coamiles" is made up of the following composition: Laguncularia racemosa, Avicennia germinans, Conocarpus erectus, and Rhizophora mangle, according to the value of importance (relative dominance + relative density + relative frequency). It is common to find them associated, in a successional process depending on the level of the tides that flood or bathe them, but establishing dominance of one species or a predominant association of two or three species depending on the place where they have settled (Table 2).

\begin{tabular}{|l|r|r|}
\multicolumn{1}{|c|}{ Scientific name } & \multicolumn{1}{c}{$\begin{array}{c}\text { Absolute } \\
\text { Dominance }\end{array}$} & $\begin{array}{c}\text { Relative } \\
\text { Dominance }\end{array}$ \\
\hline Laguncularia racemosa & 1.905 & 54.01 \\
\hline Avicennia germinans & 1.341 & 38.03 \\
\hline Conocarpus erectus & 0.230 & 6.51 \\
\hline Rhizophora Mangrove & 0.051 & 1.45 \\
\hline Total & $\mathbf{3 . 5 2 6}$ & $\mathbf{1 0 0}$ \\
\hline
\end{tabular}

Table 2 Dominance of mangrove species

In the Arroyo los Coamiles estuary the Laguncularia racemosa species prevails, with a percentage of dominance of $54 \%$ and a relative frequency of $53.45 \%$.

The structure of the mangrove begins on the left bank of the estuary with a fractionated strip formation, where the species Laguncularia racemosa and Avicennia germinans predominate.

This section has a very marked slope, in less than 4 meters it generates an elevation of more than meter and a half, causing an abrupt cut in the distribution of these species and preventing their propagation to higher areas. (Figure 2).

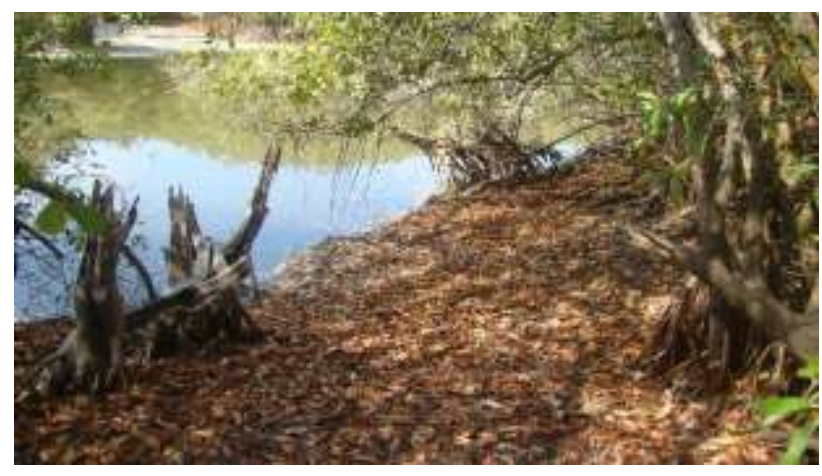

Figure 2 Fractional strip mangrove

On the right bank from the mouth of the estuary to the innermost part, an increase in its forest structure can be seen as it becomes a rimtype mangrove. (Figure 3).

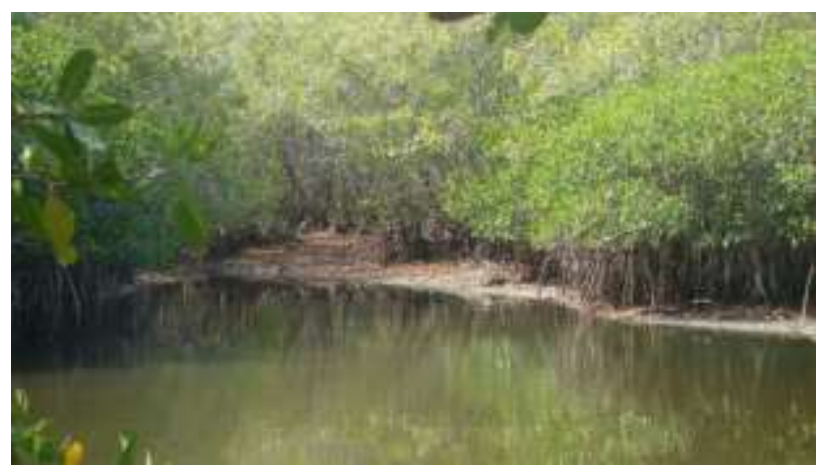

Figure 3 Mangrove edge type

In the second third of the extension of the mangrove from the mouth of the estuary towards the interior, there is the greatest development of the forest structure of the mangrove, with an edge-continental type formation (Figure 4).

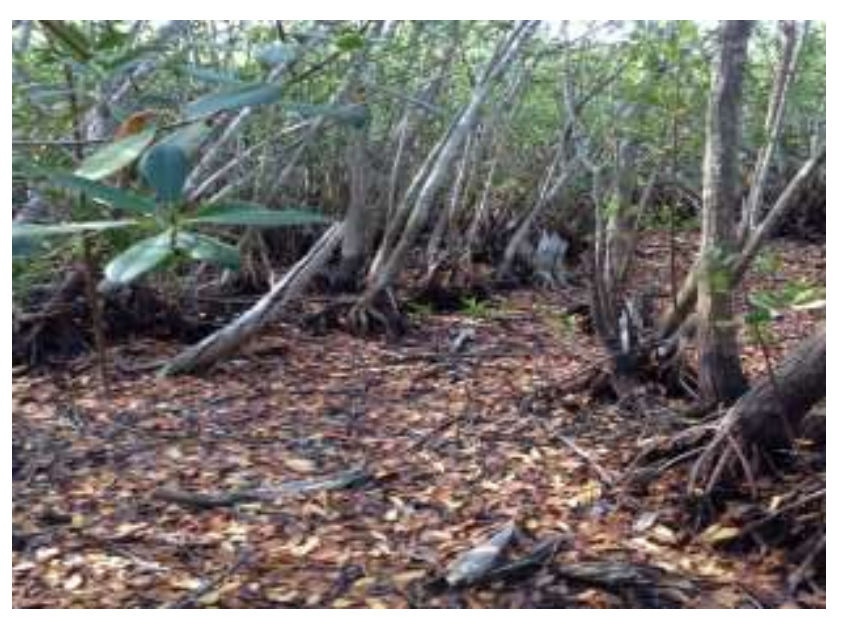

Figure 4 Edge-continental manglar

PÉREZ-PEÑA, Martín \& ROBLES-JARERO, Elva Guadalupe. Evaluation of the mangrove system in the estero "Arroyo los Coamiles" (Punta de Mita, Nayarit, Mexico). Journal of Environmental Sciences and Natural Resources. 2020 
The site presents mangrove specimens in a good state of recovery, with practically homogeneous leaf coverage over an overwashed basin. This bank presents a moderate slope with some marsh vegetation on the outer edge of the mangrove. (Figure 5).

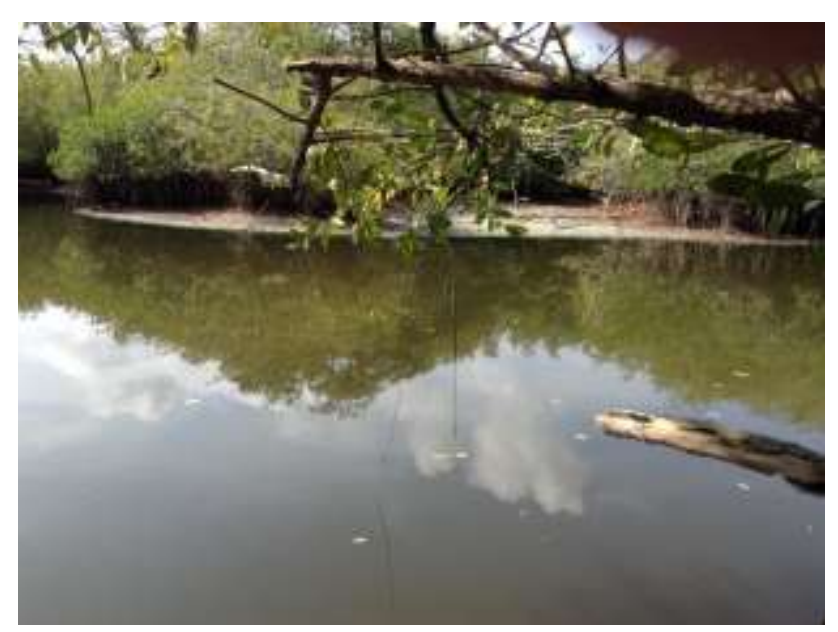

Figure 5 Mangrove basin-over-wash type

The distribution of species and average height $(\mathrm{m})$ of individuals in an elevation gradient is shown in Figure 6.

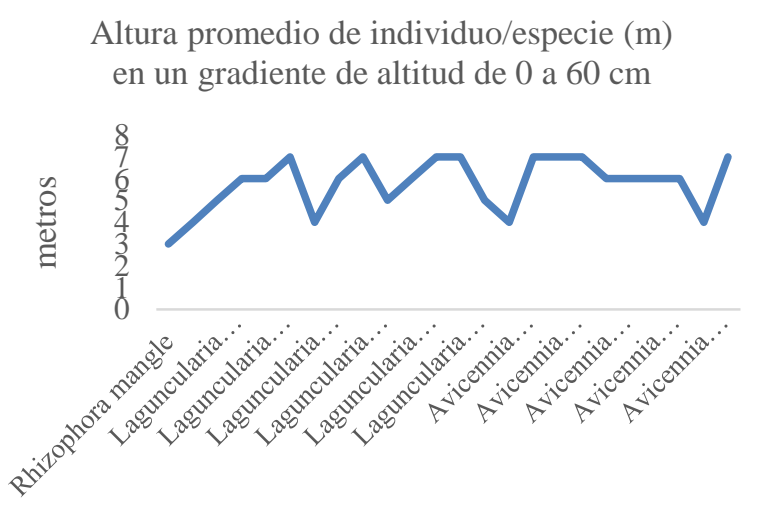

Especies de manglar

Figure 6 Species distribution and average height of individuals in an elevation gradient from 0 to $60 \mathrm{~cm}$ at sampling point 4

The average height of all species was $6.17 \mathrm{~m}$ with a standard deviation of 7.25 which indicates differences in height magnitude between species, as the standard deviation was reduced between individuals of the same species. The percentage of relative coverage by species is shown in Figure 7.
Porcentaje de cobertura relativa por especie

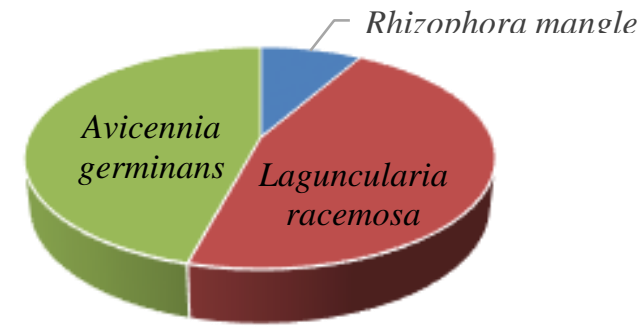

Figura 7 Porcentaje de cobertura relativa por especie, en el punto de muestreo 4

The data are associated with young trees in good state of development and conservation. With respect to the forest potential and based on the values obtained from the structural composition of the mangrove vegetation, it is defined that the forest does not have a timber potential. However, the ecological importance of the ecosystem is relevant because of its plant community dynamics represented by L. racemosa.

As for the organic matter content, the speed and balance between mineralization and humification processes, which are conditioned by microbial activity in the soil, is more relevant than the total content of this one. It should be noted that no trends or patterns can be deduced because it is a single sample over time and the great heterogeneity of the data can be attributed to the strong dynamics that the rainy season imposes on these systems (Table $3)$.

\begin{tabular}{|l|r|r|r|r|}
\hline SITES & \multicolumn{1}{|c}{ MO\% } & \multicolumn{1}{c|}{$\mathbf{C}$} & \multicolumn{1}{c|}{ C/N } \\
\hline M1 P0 & 1.78 & 0.16 & 1.03 & 6.6 \\
\hline M1 P1 & 2.04 & 0.15 & 1.18 & 7.69 \\
\hline M1 P2 & 5.23 & 0.24 & 3.04 & 12.46 \\
\hline M1 P3 & 4.12 & 0.64 & 2.39 & 3.74 \\
\hline M1 P4 & 8.04 & 0.36 & 4.66 & 13.06 \\
\hline M2 P0 & 2.88 & 0.13 & 1.67 & 13.07 \\
\hline M2 P1 & 1.45 & 0.1 & 0.84 & 8.56 \\
\hline M2 P2 & 2.47 & 0.12 & 1.43 & 12.34 \\
\hline M2 P3 & 4.74 & 0.25 & 2.75 & 11.15 \\
\hline M2 P4 & 4.34 & 0.28 & 2.51 & 8.85 \\
\hline M3 P0 & 1.7 & 0.05 & 0.98 & 7.71 \\
\hline M3 P1 & 1.75 & 0.13 & 1.01 & 10.36 \\
\hline M3 P2 & 2.98 & 0.14 & 1.73 & 14.91 \\
\hline M3 P3 & 2.87 & 0.12 & 1.66 & 6.75 \\
\hline M3 P4 & 3.61 & 0.18 & 2.09 & 7.37 \\
\hline
\end{tabular}

Table 3 Average values of organic matter percentages $(\mathrm{MO} \%)$ and Carbon-Nitrogen ratio $(\mathrm{C} / \mathrm{N})$ 
The $\mathrm{C} / \mathrm{N}$ ratio is an index of the quality of the organic soil substrate. It indicates the rate of nitrogen available to plants; high values mean that organic matter decomposes slowly, since microorganisms immobilize nitrogen, so it cannot be used by plants; values between 10 and 14 , on the other hand, correspond to rapid mineralization and tissue breakdown, since microbial activity is stimulated, there are sufficient nutrients for microorganisms and plants (Gamarra et al., 2017).

In this study the $\mathrm{C} / \mathrm{N}$ ratio of soil bacteria and fungi was less than 15 , which implies that in this range of low $\mathrm{C} / \mathrm{N}$ values, microorganisms will be more efficient in the decomposition of organic matter. This benefits the system, since it acts as a carbon sink, making the mineralization faster and avoiding $\mathrm{CH} 4$ methane emissions, also participating in the sequestration of atmospheric carbon in the form of $\mathrm{CO} 2$ through photosynthesis, reinforcing the argument of the ecological importance of this system (Gamarra, et al. 2017).

With respect to the hydrological dynamics of this estuary, there is no evidence that it connects to the sea, even during live tides, however, during the rainy season it is possible to favor the connection with the sea by overflowing, it was investigated through direct communication that the local inhabitants open a communication channel to the sea so that marine species of fishing use can enter only during the summer, according to the conductivity reading there is no filtration of salt water so most of the year is fresh water. (Herrera, et al., 2016)

It should be noted that according to water quality studies, the basin does not present values in the parameters and variables measured that indicate any type of alteration or disturbance, which indicates that the water body that supports this system and the nearby basin that feeds it are in good condition, reinforcing the idea of the functionality of this ecosystem (García Velasco et al., 2019).

\section{INEGI}

The fragility of the soils, described in

https://www.inegi.org.mx/temas/edafologia/, reinforces the proposal of taking care of the natural drainage of the property, including taking care of and preserving the quality and physiographic characteristics of the small basin that have an impact on the maintenance of water quality.

The deterioration of mangrove ecosystems and their associated wetlands (marshes, coastal lagoons) can be gradual or immediate due to various causes: drying out and/or filling in for their transformation into human settlements, ports, tourist infrastructure, agricultural activities and their use as a receiving body for residual, urban and industrial water. According to the above, it is essential to implement a follow-up program of the structural characteristics of the mangrove, of the vegetal community of the estuary and of the quality of its waters, to achieve an updated and complete diagnosis of the ecosystem and to identify affectations or modifications. These actions will allow establishing management strategies of probable contingencies and minimizing possible damages in these environments.

\section{Acknowledgements}

This study was part of an integral project of the company Geoservicios, S.A. de C.V. We thank their staff for the logistic support and the collaboration in field of Biol. Alfredo Frías Castro and Biol. Alejandro Castro.

\section{Conclusions}

In the estuary there are 4 species of mangrove reported for Mexico, with a dominance of the species Laguncularia racemosa. The most important forest development was observed in the second third of the estuary, from the mouth to the interior, showing a forest structure like edge-continental. The trees were appreciated in young stages and in good state of conservation according to the basal area.

In relation to the organic matter, the process of mineralization and humification prevails, which is conditioned by the microbial activity, more than the total content of this one. These elements must be monitored to observe the trends of variation over time. 
The $\mathrm{C} / \mathrm{N}$ ratio with values lower than 15 as in this study, implies that the system behaves as a carbon sink by fixing atmospheric $\mathrm{CO} 2$ for photosynthesis and making the decomposition of organic matter more efficient. avoiding methane emissions.

\section{References}

Basáñez, A.J., J.L. Alanis y E. Badillo. (2008). "Composición florística y estructura arbórea de la selva mediana subperennifolia del ejido el Remolino, Papantla, Veracruz". Avances de Investigación Agropecuaria. Universidad de Colima, 12: 3-22.

Cauwet G. (2002). DOM in the coastal zone. In: Hansell, DA y CA Carlson (Eds.) Biogeochemistry of Marine Dissolved Organic Matter. Elsevier Science (USA): Cap. 12: 579609.

CONABIO. (2008). Manglares de México. Comisión Nacional para el Conocimiento y Uso de la Biodiversidad, México, D.F.

CONAGUA, Comisión Nacional del Agua. (2015).

Cottam B and J Curtis. (1956). Use of distance measures in phytosocial sampling. Ecology, 37:451-460.

Dittmar T y RJ Lara. (2001). Molecular evidence for lignin degradation in sulfate reducing mangrove sediments (Amazonia, Brazil). Geochim. Cosmochim. Acta, 65: 14031414.

Dittmar T, RJ Lara y G Kattner. (2001). River or mangrove? Tracing major organic matter sources in tropical Brazilian coastal waters. Marine Chemistry, 73: 253-271.

Flores-Verdugo F, F González-Farias, D Segura \& P Ramírez, 1992. Mangrove ecosystems of the Pacific coast of Mexico: distribution, structure, litterfall and detritus dynamics. In: Seeliger, U. (Ed.) Coastal plant communities of Latina America. Academic Press. San Diego, Cal. Cap. 17: 269-288.

Fuentes, J. L. (1999). El suelo y los fertilizantes. 5ta ed. Madrid-ES. MundiPrensa.352 p.
Gamarra Lezcano Cynthia Carolina, Díaz Lezcano Maura Isabel, Vera de Ortíz Mirtha, Galeano María del Pilar, Nicolás Cabrera Antero José (2017). Relación carbononitrógeno en suelos de sistemas silvopastoriles del Chaco paraguayo Revista Mexicana de Ciencias Forestales Vol. 9 (46)

García Velasco Javier, Orozco Medina Martha Georgina, Casas Solís Josefina, Guitrón López Marcela, Mejía Sustaita Luis Edgar, Álvarez Montes José de Jesús. (2019). Estudios de calidad del agua en el estero "Arroyo los coamiles. Informe Técnico, abril. Universidad de Guadalajara Departamento de Ciencias Ambientales, CUCBA.

Herrera Silveira, J. A., A. Camacho R., E. Pech, M. Pech, J. Ramírez R. y C. Teutli H. (2016). Dinámica del carbono (almacenes y flujos) en Manglares de México. Terra Latinoamericana 34: 61-72.

Instituto Nacional de Estadística y Geografía (INEGI) en Internet www.inegi.org.mx, https://www.inegi.org.mx/temas/edafologia/

López-Portillo, J.A. and Ezcurra, E. (2002) Los manglares de Mexico: Una revisión. Madera y Bosques, 27-51.

Mueller-Dombois, $D$. and Ellenberg, H. (1974) Aims and Methods of Vegetation Ecology. John Wiley and Sons, New York, $547 \mathrm{p}$.

Tovilla Hernández Cristian. (1994). Lagunas Costeras y el litoral mexicano, Universidad Nacional Autónoma de México-Universidad Autónoma de Baja California Sur, 371-423 p. 